\title{
An Intramolecular Addition of a Hemiacetal Hydroxy Group to an Allene
}

\author{
Nils Olav Nilsen, ${ }^{\mathrm{a}}$ Lars Skattebøl' ${ }^{\mathrm{b}}$ and Yngve Stenstrøm ${ }^{\mathrm{b}}$
}

${ }^{a}$ Borregaard Ind. Ltd., N-1700 Sarpsborg and ' ${ }^{b}$ Department of Chemistry, University of Oslo, Post Box 1033, Blindern, N-0315 Oslo 3, Norway

\begin{abstract}
Nilsen, N. O., Skattebøl, L. and Stenstrøm, Y., 1987. An Intramolecular Addition of a Hemiacetal Hydroxy Group to an Allene. - Acta Chem. Scand., Ser. B 41: 459-461.
\end{abstract}

In connection with our interest in the synthesis of pheromones containing cyclobutane rings, ${ }^{1-3}$ large quantities of the allenic aldehydes 1 were needed. All three aldehydes are readily obtainable ${ }^{2,4-7}$ in low to moderate yields (35-54\%) from isobutyraldehyde and the appropriate propargylic alcohol via a Claisen-Cope type rearrangement (Scheme 1). For all three aldehydes 1a-c, simple distillation left a significant amount of residual tars, viz. 40,20 and $15 \%$ by weight, respectively. According to GLC analyses the distillates consisted of complex mixtures of which the allenic aldehydes 1 constituted the major components. In the distillate containing $1 \mathrm{c}$ a second major component was present; the ratio between this compound and 1c was 1:3.8, and they were separated by fractional distillation. The former was isolated as a white, crystalline compound and identified as the dihydropyran $2 c$ on the basis of spectroscopic evidence. The molecular weight was found from chemical ionisation MS to be 222. An IR absorption band at 3300 $\mathrm{cm}^{-1}$ indicated a terminal alkyne. Surprisingly, no absorption due to the $\mathrm{C} \equiv \mathrm{C}$ stretching vibration was observed, but the NMR spectra were in accord with the proposed structure. In the ${ }^{13} \mathrm{C}$ NMR spectrum the two alkyne carbons appear with ${ }^{1} J_{\mathrm{CH}}=249 \mathrm{~Hz}$ and ${ }^{2} J_{\mathrm{CH}}=49 \mathrm{~Hz}$, which are nearly identical with those found for acetylene itself. ${ }^{8}$ The ${ }^{1} \mathrm{H}$ NMR shifts correspond well to those of the analogues carbocycle 2-hydroxy3,3,6,6-tetramethylcyclohex-4-enone, reported recently. ${ }^{9}$ Chemical evidence for the acetal na-
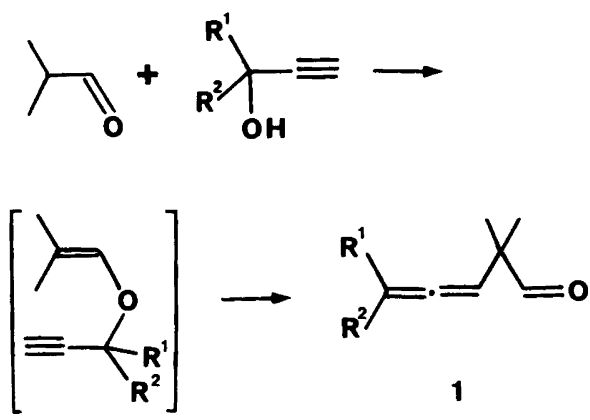

Scheme 1.

a: $R^{1}=R^{2}=H$
b: $R^{1}=H ; R^{2}=C_{3}$
c: $R^{1}=R^{2}=C_{3}$

ture of the compound was obtained from the fast and quantitative conversion of $2 \mathrm{c}$ to compounds $2 d$ and $2 e$ in the presence of an excess of methanol and 2-propanol, respectively.

The most likely pathway for the formation of $2 \mathrm{c}$ seems to be via 1c, as depicted in Scheme 2 . The mechanism is supported by reports in the literature that both phenolic ${ }^{10}$ and alcoholic ${ }^{11}$ hydroxy groups can add intramolecularly to an allene under acidic conditions. Further evidence for our mechanistic proposal was obtained from the reaction of the aldehyde $1 c$ with an excess of methanol or 2-propanol in the presence of a catalytic amount of $\mathrm{HgSO}_{4}$; heating under reflux for 4-6 $\mathrm{h}$ resulted in quantitative yields of $2 \mathrm{~d}$ and $2 \mathrm{e}$, respectively. Applying the same reaction conditions to the aldehydes $1 \mathrm{a}$ and $\mathbf{1 b}$, mixtures of 


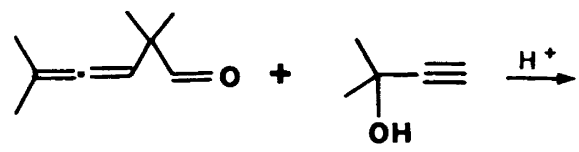

1c<smiles>C#CC(C)(C)OC1OC=CC(C)(C)C1OCC[CH+]C#CC(C)(C)OC(O)C(C)(C)C=C=C(C)C</smiles>

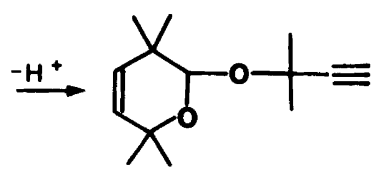

2c<smiles>[R]OC1OC(C)(C)C=CC1(C)C</smiles>

2

\author{
d: $\mathrm{R}=\mathrm{CH}_{3}$ \\ e: $\mathrm{F}=\left(\mathrm{CH}_{3}\right)_{2} \mathrm{CH}$
}

Scheme 2.

products resulted in which no single component constituted more than $30 \%$ as indicated by GLC. On the other hand, treatment of $1 \mathrm{c}$ with 2-methyl-3-butyn-2-ol, methanol or 2-propanol in the presence of $p$-toluenesulfonic acid under reflux afforded mixtures of compounds containing 2c, 2d and 2e, respectively, as major products. The reactions were very slow, requiring more than $100 \mathrm{~h}$ for completion. Similar reactions with the aldehydes 1a and $\mathbf{1 b}$ resulted in complex mixtures which were not investigated further.

The formation of $2 c$ as a by-product seems unavoidable under the reaction conditions employed for the preparation of 1c, though the yield of the former is favoured by long reaction times. The formation of $2 c$ is a novel example of an intramolecular addition to the allenic linkage, a reaction well documented for allenic alcohols. ${ }^{12}$

\section{Experimental}

General. GLC analyses were performed using a $25 \mathrm{~m}$ capillary SP 2100 SCOT column. IR spectra were recorded on a Perkin-Elmer 1310 instrument. Routine ${ }^{1} \mathrm{H}$ NMR spectra were recorded on a Varian EM 360 A instrument, high-field NMR spectra on a Varian XL-300 instrument and MS spectra ona GLC/MS VG micromass $7070 \mathrm{~F}$.
General for the syntheses of the allenic aldehydes 1. The reactions were carried out as described in the literature,,$^{2,4-7}$ starting with $1.0-1.5 \mathrm{~mol}$ of isobutyraldehyde and $1.0 \mathrm{~mol}$ of the appropriate propargylic alcohol. Simple distillation of the resulting reaction mixture separated it into a volatile fraction and a tarry residue. The volatile material was analyzed by GLC and the amount of 1 is reported as per cent of the volatiles corrected for solvent and unreacted starting materials. The amount of residue is reported as weight $\%$ based on the weight of the starting materials.

Reaction of isobutyraldehyde and 2-propynol. The aldehyde 1a was isolated as the only major compound in $42 \%$ yield; the remaining material consisted of a complex mixture of compounds.

Reaction of isobutyraldehyde and 3-butyn-2-ol. The aldehyde was isolated in $56 \%$ yield as the only major volatile compound.

Reaction of isobutyraldehyde and 2-methyl-3-butyn-2-ol. In the volatile fraction, compounds $1 c$ and $2 \mathrm{c}$ were present in a ratio of 3.8:1. Fractional distillation gave $1 c$ and $2 c$ in 50 and $13 \%$ yields, respectively. The white, crystalline compound $2 \mathrm{c}$ was further purified by sublimation $\left(60^{\circ} \mathrm{C} / 10\right.$ $\mathrm{mmHg}$ ). 
3,6-Dihydro-2-(1,1-dimethyl-2-propynoxy)-

3,3,6,6-tetramethyl-2H-pyran (2c). M.p. 59$60^{\circ} \mathrm{C}$, b.p. $102-104^{\circ} \mathrm{C} / 30 \mathrm{mmHg}$. $\mathrm{MS}\left[\left(\mathrm{CI}, \mathrm{CH}_{4}\right)\right.$; $m / z]: 223(\mathrm{M}+1), 139\left(\mathrm{M}^{+}-\mathrm{C}_{5} \mathrm{H}_{7} \mathrm{O}, 100 \%\right)$. MS[IP $70 \mathrm{eV} ; \mathrm{m} / z$ (\% rel.int.)]: 207 (0.8), 139 (10), 110(100), 95(66), 67(26), 55(13), 43(40), 41 (36), 39(17). IR $\left(\mathrm{CCl}_{4}\right): 3300(\mathrm{~m}), 3060(\mathrm{w})$, 2970(m), $2930(\mathrm{~m}), 2900(\mathrm{w}), 2865(\mathrm{~m}), 1465(\mathrm{~m})$, $1370(\mathrm{~m}), 1360(\mathrm{~m}) \mathrm{cm}^{-1}$. ${ }^{1} \mathrm{H}$ NMR $(300 \mathrm{MHz}$, $\left.\mathrm{CDCl}_{3}\right): \delta 0.97(\mathrm{~s}, 3 \mathrm{H}), 0.99(\mathrm{~s}, 3 \mathrm{H}), 1.29(\mathrm{~s}, 3 \mathrm{H})$, $1.32(\mathrm{~s}, 3 \mathrm{H}), 1.52(\mathrm{~s}, 3 \mathrm{H}), 1.58(\mathrm{~s}, 3 \mathrm{H}), 2.41(\mathrm{~s}$, $1 \mathrm{H}), 4.96(\mathrm{~s}, 1 \mathrm{H}), 5.39(\mathrm{~d}, J=10.8 \mathrm{~Hz}, 1 \mathrm{H}), 5.41$ $(\mathrm{d}, J=10.8 \mathrm{~Hz}, 1 \mathrm{H}) \cdot{ }^{13} \mathrm{C}$ NMR $(75 \mathrm{MHz}$, $\left.\mathrm{CDCl}_{3}\right): \delta 21.3\left(\mathrm{CH}_{3}\right), 24.9\left(\mathrm{CH}_{3}\right), 26.2\left(\mathrm{CH}_{3}\right)$, $29.5\left(\mathrm{CH}_{3}\right), 29.9\left(\mathrm{CH}_{3}\right), 30.5\left(\mathrm{CH}_{3}\right), 35.7$ (c), $71.6(\mathrm{O}-\mathrm{C}), 72.1\left(\equiv \mathrm{C}-\mathrm{H},{ }^{1} J_{\mathrm{CH}}=249 \mathrm{~Hz}\right), 74.9$ $(\mathrm{O}-\mathrm{C}), \quad 86.8\left(\equiv \mathrm{C}, \quad{ }^{2} J_{\mathrm{CH}}=49 \mathrm{~Hz}\right), \quad 98.0$ $\left(\mathrm{O}-\mathrm{CH}-\mathrm{O},{ }^{1} J_{\mathrm{CH}}=156 \mathrm{~Hz}\right), 131.9(=\mathrm{CH}), 133.3$ $(=\mathrm{CH})$.

Exchange reaction of $2 \mathrm{c}$ with alcohols. Solutions of $2 \mathrm{c}(1.00 \mathrm{~g}, 4.5 \mathrm{mmol})$ in methanol or 2-propanol $(20 \mathrm{ml})$ with catalytic amounts of $p$-toluenesulfonic acid were heated under reflux for 10 $\min$ or $1 \mathrm{~h}$ to give complete conversion to $2 \mathrm{~d}$ and 2e, respectively.

3,6-Dihydro-2-methoxy-3,3,6,6-tetramethyl-2Hpyran (2d). ${ }^{1} \mathrm{H}$ NMR (300 MHz), $\left.\mathrm{CDCl}_{3}\right): \delta 0.97$ $(\mathrm{s}, 6 \mathrm{H}), 1.28(\mathrm{~s}, 3 \mathrm{H}), 1.29(\mathrm{~s}, 3 \mathrm{H}), 3.46(\mathrm{~s}, 3 \mathrm{H})$, $4.29(\mathrm{~s}, 1 \mathrm{H}), 5.36(\mathrm{~d}, J=10.0 \mathrm{~Hz}, 1 \mathrm{H}), 5.45(\mathrm{~d}, J$ $=10.0 \mathrm{~Hz}, 1 \mathrm{H}) \cdot{ }^{13} \mathrm{C}$ NMR $\left(75 \mathrm{MHz}, \mathrm{CDCl}_{3}\right): \delta$ $21.5\left(\mathrm{CH}_{3}\right), 25.3\left(\mathrm{CH}_{3}\right), 26.7\left(\mathrm{CH}_{3}\right), 29.6\left(\mathrm{CH}_{3}\right)$, $35.5(\mathrm{C}), 56.2\left(\mathrm{CH}_{3} \mathrm{O}\right), 73.8(\mathrm{O}-\mathrm{C}), 103.8$ $(\mathrm{O}-\mathrm{CH}-\mathrm{O}), 131.7(=\mathrm{CH}), 132.3(=\mathrm{CH})$.

\section{3,6-Dihydro-2-(1-methylethoxy)-3,3,6,6-tetra-}

methyl-2H-pyran (2e). MS[CI, $\left.\left.\mathrm{CH}_{4}\right) ; \mathrm{m} / \mathrm{z}\right]: 199$ $(\mathrm{M}+1), 139\left(\mathrm{M}^{+}-\mathrm{C}_{3} \mathrm{H}_{7} \mathrm{O}, 100 \%\right)$. MS[IP $70 \mathrm{eV}$; $m / z$ (\% rel. int.)]: 197(0.1), 111(15), 110(100), 95 (98), 81(10), 69(10), 67(16), 55(17), 43(51), 41 (35), 39(12). ${ }^{1} \mathrm{H}$ NMR (300 MHz, $\left.\mathrm{CDCl}_{3}\right): \delta 0.94$ (s, 3H), $0.98(\mathrm{~s}, 3 \mathrm{H}), 1.14(\mathrm{~d}, J=6.1 \mathrm{~Hz}, 3 \mathrm{H})$, $1.24(\mathrm{~d}, J=6.1 \mathrm{~Hz}, 3 \mathrm{H}) 1.28(\mathrm{~s}, 3 \mathrm{H}), 1.29(\mathrm{~s}$, $3 \mathrm{H}), 3.92$ (heptet, $J=6.1 \mathrm{~Hz}, 1 \mathrm{H}), 4.47(\mathrm{~s}, 3 \mathrm{H})$, $5.37(\mathrm{~d}, J=10.0 \mathrm{~Hz}, 1 \mathrm{H}), 5.43(\mathrm{~d}, J=10.0 \mathrm{~Hz}$, 1H). ${ }^{13} \mathrm{C} \mathrm{NMR}\left(75 \mathrm{MHz}, \mathrm{CDCl}_{3}\right): \delta 21.3\left(\mathrm{CH}_{3}\right)$, $21.7\left(\mathrm{CH}_{3}\right), 23.3\left(\mathrm{CH}_{3}\right), 25.0\left(\mathrm{CH}_{3}\right), 26.4\left(\mathrm{CH}_{3}\right)$,
$29.8\left(\mathrm{CH}_{3}\right), \quad 35.4(\mathrm{C}), 69.8(\mathrm{O}-\mathrm{CH}), \quad 7.39$ $(\mathrm{O}-\mathrm{C}), 99.9(\mathrm{O}-\mathrm{CH}-\mathrm{O}), 131.8(=\mathrm{CH}), 132.8$ $(=\mathrm{CH})$.

Synthesis of 2c catalyzed by $\mathrm{HgSO}_{4}$. Mixtures of 1c $(1.00 \mathrm{~g}, 7.2 \mathrm{mmol})$, methanol or 2-propanol $(20 \mathrm{ml})$ and $\mathrm{HgSO}_{4}(150 \mathrm{mg}, 0.51 \mathrm{mmol})$ were heated under reflux for $4-6 \mathrm{~h}$ to give quantitative yields of $2 d$ and $2 e$, respectively.

Reaction of 1c with alcohols. Solutions of $1 \mathrm{c}(1.00$ $\mathrm{g}, 7.2 \mathrm{mmol}$ ) and a catalytic amount of $p$-toluenesulfonic acid in either 2-methyl-3-butyn-2-ol, methanol or 2-propanol $(20 \mathrm{ml})$ were heated under reflux for $\sim 100 \mathrm{~h}$. The reactions were monitored by GLC. Neutralization with $\mathrm{Na}_{2} \mathrm{CO}_{3}$, drying $\left(\mathrm{MgSO}_{4}\right)$ and evaporation followed by shortpath distillation gave $\mathbf{2 c}, \mathbf{2 d}$ and $2 \mathbf{e}$, respectively, in $50-60 \%$ yields.

\section{References}

1. Skattebøl, L. and Stenstrøm, Y. Tetrahedron Lett. 24 (1983) 3021.

2. Skattebøl, L. and Stenstrøm, Y. Acta Chem. Scand., Ser. B 39 (1985) 291.

3. Rømming, C., Skattebøl, L. and Stenstrøm, Y. Acta Chem. Scand., Ser. B 40 (1986) 434.

4. Thompson, B. U.S.Pat. 3, 236, 869 (1966); Chem. Abstr. 64 (1966) 1728d.

5. Bly, R. S. and Koock, S. U. J. Am. Chem. Soc. 91 (1969) 3292.

6. Feller, D., Davidson, E. R. and Borden, W. T. J. Am. Chem. Soc. 106 (1984) 2513.

7. Skatteb $\varnothing l$, L., Stenstrøm, Y. and Uggerud, E. Acta Chem. Scand., Ser. B 40 (1986) 363.

8. Abraham, R. J. and Loftus, P. Proton and Carbon-13 NMR Spectroscopy, Heyden, Philadelphia, USA 1981.

9. Schaltegger, A. and Bigler, P. Helv. Chim. Acta 69 (1986) 1666.

10. Luteijn, J. M. and Spronck, H. J. W. J. Chem. Soc., Perkin Trans. 1 (1979) 201.

11. Jacobs, T. L., Macomber, R. and Zunker, D. J. Am. Chem. Soc. 89 (1967) 7001.

12. Schuster, H. F. and Coppola, G. M. Allenes in Organic Synthesis, Wiley, New York 1984, Chap. 5.

Received March 16, 1987. 